The Hour of the Star Through Media Lenses: A Tribute to Clarice Lispector (1920-2020)

\title{
THE HOUR OF THE STAR THROUGH MEDIA LENSES: A TRIBUTE TO CLARICE LISPECTOR
} (1920-2020)

\author{
Gilberto Alves Araújo \\ Federal University of Pará (Brazil) / University of the Witwatersrand - Wits (South Africa) \\ gilbertoa.araujo@yahoo.com.br \\ Eliene Rodrigues Sousa \\ Federal Institute of Tocantins / Federal University of Tocantins (Brazil) \\ liaelienerodrigues@gmail.com \\ Raquel da Silva Lopes \\ Federal University of Pará (Brazil) \\ ralopes@ufpa.br
}

Received: 12/04/2020 - Approved: 28/05/2020 - Published: 15/04/2021

DOI: doi.org/10.17533/udea.lyl.n79a17

\begin{abstract}
The criticisms of Clarice Lispector's The Hour of the Star (1977) were analyzed by (re) evaluating its relevance and the legacy of its author. After a critical review of the texts in popular publications, it was found that, in Brazil, the debates about the novel were centered between explicitness and introspection, social commitment and aesthetic sublimation. Foreign critics, on the other hand, raised Lispector's ability to reach diverse audiences and the readability of her work, including disputes over her prestige as an author among other great writers and the relevance of her compositions.
\end{abstract}

Key words: Clarice Lispector; The Hour of the Star; critique; reception; Latin American literature.

\section{LA HORA DE LA ESTRELLA MIRADA A TRAVÉS DE LAS LENTES DE LOS MEDIOS: UN HOMENAJE A CLARICE LISPECTOR (1920-2020)}

Resumen: Se analizan las críticas hechas a La hora de la estrella (1977), de Clarice Lispector, (re)evaluando su relevancia y el legado de su autora. Luego de una revisión crítica a los textos en publicaciones populares, se halló que, en Brasil, los debates sobre la novela se centraron entre la explicitud y la introspección, el compromiso social y la sublimación estética. Los críticos extranjeros, por otro lado, plantearon la capacidad de Lispector para llegar a diversas audiencias y la legibilidad de su trabajo, incluidas las disputas sobre su prestigio como autora entre otros grandes escritores y la relevancia de su obra. Palabras clave: Clarice Lispector; La hora de la estrella; crítica; recepción; literatura latinoamericana. 


\section{Introduction}

his paper intends to present, analyze and compare relevant contributions by critics in the media who dedicate themselves to discussions about the novel A hora da estrela (1977), The Hour of the Star (1986), by Clarice Lispector, considering the author's centennial in 2020 — she was born in 1920 - ; the commemorative re-edition of the novel in English by New Directions (The Hour, 2020); and the republishing of Lispector's eighteen works by the publishers Rocco (Ano, 2019), among which the novel was found to be discussed in this article. From a chronological point of view, the aim is to observe the trajectory of the mediacritical assessment of that novel to understand what conceptions and perspectives have been constructed about this work of Lispector's, as well as possible transformations and advancements which media critics or people from the general public have been able to propose through more than four decades since its first edition in Portuguese in 1977. Additionally, media texts can teach the public about Lispector's legacy not only in Brazilian and Latin American literature, but also in literature around the world.

Published in 1977, the same year of the author's death, The Hour of the Star (henceforth A-Hora) is, alongside Um sopro de vida: pulsações (1978) ${ }^{1}$ [translated as A Breath of Life (2012)] ${ }^{2}$, part of the duo that closes Lispector's literary career, also marking the end of her biography. A-Hora was written in a moment when Lispector was facing serious ovarian cancer, a disease that took her life at the age of 57, and is one of the most important and studied novels of Brazilian literature. The narrative explores the (mis)adventures of Macabéa, a woman from northeastern Brazil who migrates from the poor state of Alagoas to the city of Rio de Janeiro, where she lives —or survives, uninspired - finally dying after being run over by a Mercedes-Benz. Countless themes and reflections can be drawn from the content and architecture of this narrative, which defies its inscription into molds and has forever marked the history of literature.

Consequently, the novel has also been object of true fascination among scholars working within literary studies and correlated areas, analyzed and discussed in hundreds of articles, theses and dissertations in Brazil and abroad. Under these circumstances, presenting a new perspective on such a notable creation becomes, in fact, a challenge. Even so, it is believed that, by identifying and treating the media's critical reception of this narrative through time, it might be relevant to systematize conceptions about Lispector's contributions to art, reflected, therefore, on the aesthetic, philosophical and social nature of $A$-Hora and its impact on the general public, beyond academia. By doing so, there is a significant chance to understand some of the reasons that might substantiate such a magnetism around a novel which unsettles, at once, lay readers, editors, translators and critics.

Actually, not just through A-Hora, but since her first novel, Perto do coração selvagem (1943) ${ }^{3}$ [translated as

\footnotetext{
$\overline{1 .} \quad$ Lispector, C. (1978). Um sopro de vida: pulsações. Rio de Janeiro: Nova Fronteira.

2. Lispector, C. (2012). A Breath of Life. Novey, I. (trans.). New York: New Directions.

3. Lispector, C. (1943). Perto do coração selvagem. Rio de Janeiro: Editora A Noite.
} 
The Hour of the Star Through Media Lenses: A Tribute to Clarice Lispector (1920-2020)

Near to the Wild Heart (1990)] $]^{4}$, Lispector's writing determined a disruption in prevailing narratives' paradigms, transgressing linguistic and literary conventions. From then on, the artist managed to get the attention of renowned critics such as Antonio Candido and Roberto Schwartz. Nonetheless, she was not spared from severe and unfair reproach by those who could not comprehend the intrepidity of her art, which sometimes has been considered «trash» (Becherucci, 1974, § 6) and «unpublishable» (Moraes, 1974, § 4) by journalists of her time. Notwithstanding, more than forty years after her death, Lispector continues to arouse the interest of lay readers and scholars in Brazil and many other countries (Gildea, 2014; Moser, 2015; Dodson, 2017; Goldman, 2018; Kellogg, 2019), also reawakening popular appreciation of her creations, which circulate in iconic images, (pseudo)quotes, memes and other internet genres.

Although her prestige had been greater in academia, the chronicles Lispector wrote for Jornal do Brasil (1967-1973) enabled her to become a familiar voice to diverse readers. Despite appearing popular, the author did not cease to be an enigma. Her appreciation for privacy, discretion and isolation allowed for a mysterious aura and an almost mythical atmosphere, to be created around her; something which could ultimately refract and be refracted in her personality.

In her text for The New York Review of Books, Lorrie Moore (2009) reports some legends regarding Lispector's persona, even among scholars who study South American literature abroad. When questioning four of those professors in the U.S. about Lispector's life, one of them said she had died in a fire, and others said she had been a lesbian her whole life. Moore (2009) believes that this obscureness around Lispector makes her, even so, very charismatic.

Keeping that context in mind, it is important to reiterate that the major goal here is to present and discuss the media's critical reception of A-Hora and not necessarily all works by Lispector. To this end, this paper is divided into three sections. The first one provides general perceptions of critics in Brazilian newspapers and magazines, including texts published between 1977 and 2019, and two texts by popular Brazilian scholars. The second segment focuses on media texts from English speaking countries which circulated in the 1980s and 1990s, including one text by a Latina popular scholar. The third section expatiates on critical contributions in English language media texts ranging from 2000 to 2020. Lastly, in the conclusion the perceptions of the several critics and periodicals selected for this study are synthetized, also seeking to condense the further discussions on the identification and evaluation of Lispector's legacy in the particular case of the novel in question.

Regarding the research methodology, it is critical to point out that for this particular discussion were selected mainly media texts, which were somehow related to the discussion of the novel in question. The requirements for the chosen sources were that the texts had to be of open access, written in English or Portuguese and with at least 400 words; also, the articles should have been published between January 1st, 1974, and April 2nd, 2020, mostly in non-scholarly periodicals established before 2018, as well as in popular media outlets and in publications managed by organizations renowned either for their history or notoriety in the publishing market. Guided by those parameters, the search through publicly available sources yielded around 20 texts in Brazilian publications and 32

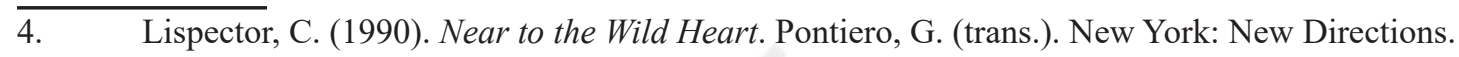


The Hour of the Star Through Media Lenses: A Tribute to Clarice Lispector (1920-2020)

more in international periodicals from the USA, England, Ireland, Canada, and Australia. Therefore, these are the media texts discussed in the following sections.

However, before the debate, it is necessary to clarify some theoretical points, which might help to ponder the results more cautiously at the end of this work. Namely, it is essential to make some distinctions between literary criticism in media and literary criticism in academia. Both types of criticism are realized through institutions that are permanent parts of the public sphere, notably newspapers, magazines and universities respectively (Eagleton, 2005; Habermas, 1991). In this sense, it has to be mentioned that, more than a stage for political engagement or democratic participation, the public sphere is the space in which members of society deliberate about common affairs; therefore, it is a site for discursive interaction, for the construction of common sense or public opinion. It is within this space, materialized in universities and periodicals, for example, that art —in this case, Lispector's novel — becomes an object of deliberation through the medium of «talk» between critics, artists and readers.

Notwithstanding, way before the formal existence of a bourgeois public sphere (Habermas, 1991) which would make possible the rise of media literary criticism, an academic literary criticism can be traced back to Ancient Greece and the Middle East, among art scholars, theologians and philosophers. Until the Renaissance, universities, churches, monasteries and their accredited intellectuals, with their legitimized knowledge, scholasticism and institutionalized roles, were the ones mostly responsible for evaluating art quality (Habib, 2005; Day, 2008). Nevertheless, the transition towards Enlightenment not only consolidated the modern idea of academia, but also started to make way for the ascension of a bourgeoisie and a consequent popularization of literature through larger production and circulation in newspapers and magazines (Habib, 2005). If in earlier stages the universities realms for literary criticism - could be considered dominions of the state, the church or the aristocracy; from the Enlightenment onwards the bourgeoisie would try to guarantee its own place in academia, while also attempting to fill in the gap between those sectors and the «commoners», or the general public from which many bourgeois citizens came. Accordingly, this public sphere arises as a project of the bourgeois classes, distinct from the state, the economy and other civil associations (Habermas, 1991), despite still being related to them. This arena is born with ideals of democratic accessibility, rational deliberation and the common «good», goals which have never been fully attained (Habermas, 1991).

In fact, during the Enlightenment, much as it is the case nowadays, the role that academic - literarycriticism would play within universities in the centuries to come became clearer: that of training «students in the effective deployment of certain techniques, in the efficient mastery of a certain discourse, as a means of certificating them as intellectually qualified recruits to the ruling classes» (Eagleton, 2005, p. 91), that is, the (neo) capitalist elites. Besides the reproduction of dominant social structures, academic literary criticism has failed to consistently arouse social interest, maintaining itself as a type of discourse which is mostly self-validating and self-perpetuating (Eagleton, 2005), more concerned about «theory» than «life» and, perhaps, more alienated from the general public — circumstances that make this paper even more relevant, since it brings into debate the discourses on literature that are beyond academia-. 
The Hour of the Star Through Media Lenses: A Tribute to Clarice Lispector (1920-2020)

On the other hand, with the ascension of the bourgeoisie and the development of a bourgeois public sphere from the Enlightenment onwards, literary criticism also gained its space within newspapers and magazines, while acquiring its current meaning of assessing the quality of an art work in both aesthetic and philosophical dimensions (Sgard, 1994). In the case of popular media, as it is today, the critics' task would entail both informing about and evaluating art objects.

The advent of these discursive spaces or periodicals would also give rise to later transformations of the idea of what literary critics are. By the end of the Enlightenment era, the figure of the «periodicalist» would be consecrated as the position which is now known as a critic. This character, often coming from the bourgeois ranks of society, becomes a «consensualist» of the newspapers and magazines, who works well with generalities and common sense. These elements, largely infused with political contentions, however, are built by the periodicalist in their reviews as results of apparent political consensus. Appealing to universal reason, the periodicalist evaluates art and the world in a way that might seem to counteract an aristocratic absolutism. Nevertheless, their positioning mostly reinforces conservativism, preaches corrections and represses deviations. Since the periodicalist is usually a member of the bourgeoisie, this attitude seems quite consistent with the 18th century «bourgeois principle of abstract free and equal exchange», which is transferred from «the market-place to the sphere of discourse», mystifying and idealizing «real bourgeois social relations» (Eagleton, 2005, p. 26).

In the Victorian age, during the 19th century, the «sage» would emerge as another kind of media critic, who would try to «rescue criticism and literature from the squalid political infighting», so familiar to periodicalists, by presenting the audience with «transcendental forms of knowledge» (Eagleton, 2005, p. 39). As so, being «transcendental» enabled the sage to retain a more authoritarian position in relation to his audience, which he was also deprived of, whether owing to the concession of literature into the hands of the market or the increasingly anonymous urbanization of societies, among other factors. Thereby, the sage's «pronouncements [become] dogmatic and self-validating» and «his posture towards social life chillingly negative» (Eagleton, 2005, p. 39).

The last iconic representative of literary criticism in media, during the Victorian age, is the «man of letters». Within an ever more commercial literary world, this figure is compelled to act as a factotum, holding onto superfluity to stay afloat and visible, resisting specialization for economic and ideological reasons, and resorting to all kinds of knowledge in order to dispense a certain general wisdom. In this sense, he is an «intellectual salesman» (Eagleton, 2005, p. 51), a role that comes quite close to what many literary media critics do nowadays. The man of letters is not as authoritarian as a sage, nor as consensual as a periodicalist, but something in between, a certain consolidator of public opinion. He is also a commentator, an educator, a consoler, an interpreter and a popularizer. By the end of the 19th century and the beginning of the 20th, and in the face of growing institutionalization of literary criticism, the man of letters was caught between academy and commerce, and he started to be despised by scholars «for his shallow eclecticism, partisanship and moral pretensions» (Eagleton, 2005, p. 66). Furthermore, the 20th century would intensify both the fragmentation of knowledge and the fragmentation of audiences, preventing media critics from maintaining an identity of interests that is more socially conceived, as opposed to 
The Hour of the Star Through Media Lenses: A Tribute to Clarice Lispector (1920-2020)

more individually created, as it is notice in contemporaneity.

Comparatively, if the periodicalists work within the hegemony of their time by mystifying it with «reason», and the sages withdraw themselves from the social arena to some higher place of reflection, the man of letters brings himself to deal with everyday life as he tries to survive, comfort and educate others. The contemporary literary critic in media, on the other hand, might be somehow related to at least one feature of each type of critic presented above. They can also be seen as a strategic mediator between managers — market agents-, writers and readers.

Within a contemporary political economy, which is increasingly competitive and deeply marked by neoliberal capitalism and consumerism, the media critic becomes an important stakeholder in the contemporary public sphere, also playing a role, alongside artists and readers, in determining the degree of material and symbolic success of an art piece, especially because they might influence not just readers' — consumers' — immediate decisions —as to whether to buy and read or ignore a novel — but also their perceptions and understanding about art and life. In this sense, more than affecting the economic fate of a book, for example, the current media critic might also help cultivate fandom or «haters» for a particular art object, develop their own faithful audience, project themself as an influencer in the public sphere and generate substantial revenue for the periodicals they work for.

Consequently, it is not surprising that, nowadays, critical reviews tend to operate more often as promotional campaigns and informative or analytical outlets than as evaluative instances (Larceneux, 2001). The media critic's responsibility now is perhaps more about handling the needs of audiences, media houses and advertisers. In spite of all that, the ideal type of media critic is still the one who manages to be independent, that is, immune to any kind of pressure (Béra, 2003). A contemporary media critic's review, therefore, should be solely based on the merits of the art piece; after all, the authenticity of their evaluation, as well as their credibility and power in the eyes of the public, would ultimately rely on that autonomy. Nonetheless, as subtly implied by the discussions below, contemporary literary critics in media are not immune to any type of influence, including economic and political, not to mention bias and the influence of their own audience, which legitimates them as relevant critics and helps them sustain media outlets.

\section{Critical Reception in Brazilian Magazines and Newspapers (1977-2019)}

Even before its publication, A-Hora had become a topic in newspapers such as $O$ Globo (Lispector, 1977) and Última Hora (Trechos, 1977), which might have created an environment conducive to a positive reception for the novel, also arousing the curiosity of the public before its circulation. Although the latter newspaper had limited itself to announcing the new narrative and publishing passages from it, similar to the promotional teasers seen nowadays, the former published an entire interview with Lispector in which she answered questions related to her writing process, the financial challenges facing a writer and the classification of her work as mystic literature by the journalistic critique. Concerning A-Hora, Lispector (1977) limited herself to saying that «it was [a book] of 
The Hour of the Star Through Media Lenses: A Tribute to Clarice Lispector (1920-2020) great inspiration and suffering» (n.p.).

It is necessary to remember that the publication of this novel was preceded by severe reprehension from Jornal do Brasil (Moraes, 1974) and Veja magazine (Becherucci, 1974) about Via crucis do corpo (1974) ${ }^{5}$ translated as Via Crucis of the Body (2015)] $]^{6}$, as well as by the announcement of disputes between Lispector and her editors (Lispector, 1976). In the face of these and other circumstances, Lispector would not only be stamped as a misanthrope, but also might not have had the opportunity to enjoy the same prestige that Paixão segundo G.H. (1964) ${ }^{7}$ [translated as The Passion According to G.H. (1988)] brought upon her. This scenario, hypothetically, could make critics lean more towards disapproving of $A$-Hora.

Nevertheless, the author's death at the end of the same year that the novel had been published might later have intensified two dynamics in the newspapers: firstly, the evaluation that seeks to extensively connect $A$-Hora with previous works by Lispector; secondly, a more evident mystification of her works and biography.

Media texts published before her death, however, seem to emphasize the idea that her novel is infused with mystique and solitude. According to the columnist from Jornal do Brasil (Habib, 1977), in A-Hora Lispector remains enigmatic through a strategy of attempts and gradual developments, even though, for him, the author had drawn herself away from an extreme introspection that characterizes many of her works. For Habib (1977), in A-Hora it is the writing process itself that becomes the protagonist, since it emerges powerful, exposed and delicate.

In $O$ Globo, Junqueira (1977) partially disagreed with Sérgio Habib by highlighting that in this novel, Lispector consolidated her introspection, as well as her ability to construct metaphorical, phenomenological and existential perspectives. At this particular point, Medeiros (1977), from Jornal do Brasil, also contradicted Habib and confirmed Junqueira's position concerning the introspective atmosphere that prevails in the narrative. Whereas for Habib (1977), Lispector breaks away from certain levels of profound introspection that used to conceal the creation process, and for Junqueira (1977) and Medeiros (1977), the composition of interactions between narrator and reader, for example, notwithstanding its ability to expose the sculpting of Lispector's art, still preserved the very personal and internal nature of the writer's style.

Accordingly, just like Medeiros (1977), Junqueira (1977) also suggested that Lispector's introspection makes her an artist of a solitary and singular aura, as suggested by the titles of their articles, which partially repeat the conception of solitude evoked by Lispector's interview with $O$ Globo (Lispector, 1977), published before the launch of the novel: «Solitary, solidary» (Medeiros, 1977), «Clarice Lispector: singular, solitary, total novelist» (Junqueira, 1977); «Clarice Lispector, another book and the same solitude» (Lispector, 1977) [emphasis added]. In this sense, Junqueira (1977) also argued that A-Hora not only expands the horizons of national fiction significantly,

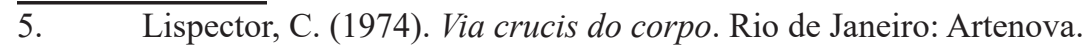

6. Lispector, C. (2015). Via Crucis of the Body. Dodson, K. (trans.). London: Penguin Classics.

7. Lispector, C. (1964). A paixão segundo G.H. Rio de Janeiro: Editora do Autor.

8. $\quad$ Lispector, C. (1988). The Passion According to G.H. Minneapolis: University of Minnesota Press.
} 
The Hour of the Star Through Media Lenses: A Tribute to Clarice Lispector (1920-2020)

but also makes an unusual way for regionalist realities, beginning with an internal viewpoint from northeastern Brazil. Besides, these critics also support, in one way or another, the idea that the expressivity of language in Lispector achieves an unprecedented purpose in problematizing being in the world, pulling away from a previous notion of a triumphant language.

It is through this problematizing language from $A$-Hora that Lispector explicitly turned her attention to social issues, according to some critics. Although there might not be enough elements to corroborate the following proposition, it is possible to assume that the author was under some pressure. She was possibly responding to demands for her creation to serve the cause of the oppressed, or to commit to the excitement over a socially engaged literature from the 1960s and 1970s, as well as to a national identity project, which was, at that time, being implemented by agents of the Brazilian military dictatorship.

Arêas (1977) and Ribeiro (1977) were among the columnists who paid greater attention to social aspects in A-Hora. Unlike some of the journalists mentioned so far, Arêas (1977) believed that, in this particular novel, Lispector did not mystify, nor did she aestheticize the reality nor mask distinctions between socioeconomic classes. For Arêas (1977), the writer admitted the paradoxes in order to reformulate them as a way of questioning structures from the status quo, whether the latter are components of social life or literature itself.

Ribeiro (1977) seemed to go beyond that when he stated that the approach on social aspects was already present in many of Lispector's previous works, and even back then in A-Hora. For the journalist, in this and other novels, the writer displayed a wealth of social viewpoints and painfully captured the truth, instituting, therefore, a literature of the powerless.

In a comparable manner, Rawet (1979) also maintained that Lispector was already socially engaged in previous works, prior to A-Hora. These words remind that, like in many other novels, the novelist presented herself as a woman, sometimes foreign, but always a Brazilian northeasterner, which already pointed out the social dimension in her art, notwithstanding the fact that she was an ambassador's wife and came from a family of painters and art critics, potentially enjoying greater privileges, as suggested by some (Wilmington, 1987; Moore, 2009).

Whereas many Brazilian commentators and literary critics themselves demanded and encouraged a sociopolitical engagement in art, or perhaps the construction of a Brazilian identity through fiction, Rawet (1979) and others were concerned about demonstrating that there is more than one form of engagement, beyond the obvious and objective way many people expect. In his essay, Rawet (1979), a Polish-Brazilian intellectual, opposed Portella (1977), whom he saw as part of a «Brazilian literature police», dictating and selecting parameters for the construction of the Brazilian identity in Lispector's A-Hora, without, however, examining the writer's production as a whole.

In turn, Portella (1977) seemed to contradict Junqueira (1977), Medeiros (1977) and Ribeiro (1977) at the same time, taking Habib's perception (1977) even further when considering that in A-Hora the author revealed herself as «new, external and explicit [...], committed to a project on northeastern Brazil» (Portella, 1977, cited in Rawet, 2008 [1979], p. 218). When responding to Portella's proposition, Rawet (2008 [1979]) argued precisely 
The Hour of the Star Through Media Lenses: A Tribute to Clarice Lispector (1920-2020)

the opposite of that, quoting passages from Agua viva (1973) ${ }^{9}$ [translated as Stream of Life (1989) ${ }^{10}$. For the latter, a project on northeastern Brazil was already present in the abovementioned novel, long before $A$-Hora. According to him, Portella (1977) did not understand it and violated the sensitivity of Lispector's spirit for parody. Then, Rawet (1979) warned Portella and others about the risks of not distinguishing between a sociopolitical engagement project and an initiative for the construction of a Brazilian identity. For him, the same totalitarianism of the Brazilian dictatorship, as in IA- $5^{11}$, was covertly present among Brazilian critics, who wanted to standardize in A-Hora the acceptability of different forms of engagement and the type of literature able to implement that identity project.

This standardization may be even more evident in the case of Eduardo Portella, a servant of the Brazilian military dictatorship who was later fired by the generals of the government, and who also, alongside other critics of his time, emphasized the need for the development of a nationalist Brazilian identity and a demand for a more representational literature. Nevertheless, as implied by Rawet (1979), in A-Hora and many other works Lispector perhaps goes against the abovementioned movement, resorting to the tradition of power discourses, nationalism and religion in order to confront, infringe or transmute them, not to replicate them, as Portella suggests.

Regardless of those vehement controversies around A-Hora, the work would remain alive in Brazilian ( $A$ Hora, 1986; Cancino, 1999) and foreign publications (Wilmington, 1987; Maslin, 1987; Rich, 1998) throughout the 1980s and 1990s, thanks to, among other factors, its cinematographic adaptation by director Suzana Amaral. In fact, this production won several international awards, including some at the Berlin Festival in 1986.

In Brazil, many media texts published between 2000 (Alves, 2008) — when reading A-Hora became mandatory in many university entrance exams - and the first half of the 2010s (Guedes, 2015) started to prepare the ground for the celebration of the 40 years of the novel's publication, and later the festivities around Lispector's centennial of her birth (Ianelli, 2019; Obra, 2019). These texts confirm the prestige obtained by Lispector and reinforce the ideas of mystery, linguistic eccentricity and exploration/contemporaneity of $A$-Hora's existential dimension, with a focus on the drama of being human in post-modernity. In this sense, the last two elements, an aesthetic and a philosophical one, are the most emphasized when A-Hora is mentioned.

Publications at the end of the 2010s also aimed to announce adaptations of A-Hora into plays and musicals (A Hora, 2017), as well as seeking to highlight the currency of the themes presented in A-Hora (Maciel, 2017). Furthermore, they rescue notions of intimism, feminist engagement, aesthetic innovation (Moscovich, 2017; Maciel 2017) and dilemmas managed by Lispector in her creation process; an artist who faced a demand for a Brazilian identity project which requires a fiction guided by certain standards as she also tried to handle the transgressive spirit that was so typical of her character. These two realities end up converting themselves into the projection of two reading audiences: «there's a more linear story [...], [for] a wider audience [...], [but she] also

9. $\quad$ Lispector, C. (1973). Água viva. Rio de Janeiro: Artenova.

10. Lispector, C. (1989). Stream of Life. Minneapolis: University of Minnesota Press.

11. One of the decrees issued by the Brazilian military dictatorship after the 1964 coup d'état, which suspended legislative bodies, authorized the executive to rule by decree, and provided legal basis for a purge of political critics. 
The Hour of the Star Through Media Lenses: A Tribute to Clarice Lispector (1920-2020)

embraces a side that is typically Lispector. [...] There's this experimental side [...], but there is also the accessible one» (Maciel, 2017, § 7).

\section{Critical Reception in Foreign Media Throughout the 1980s and 1990s}

Abroad, one of the first and most notorious approaches on A-Hora did not come from media, but from academia, from French theoretician Hélène Cixous's works. Her critical analyses of Lispector's art, from the 1970s to 1990s, not only contributed to distinguishing the Brazilian author in Europe and North America, but also made a way for new perspectives of study about her works, with an emphasis on philosophy and feminist writing conceptions also in A-Hora.

Nevertheless, A-Hora's first translation was not into French, but into Czech (Okamžik pro hvězdu [«A Moment for the Star»]), by Přeložila Pavla Lidmilová in 1981, three years before reaching francophone readers. Later, versions in French (1984; 1985), German (1985), English (1986), Polish (1987), Dutch (1988), Argentinian Spanish (1989), European Spanish (1989), Italian (1989) and Danish (1989) were published, closing, therefore, the cycle of its translations in the 1980s. The 1990s and the beginning of the 2000s also witnessed re-editions of A-Hora in the abovementioned languages, or other versions into new languages.

In any case, it was Giovanni Pontiero's version, published in 1986 by Carcanet Press, which introduced A-Hora to speakers of English, the most common language among non-native users. The appraisal by Kirkus Reviews Issue, in the same year as the novel's publication, is a very short comment that limits itself to pointing out the profound pain and tenderness imbued in Lispector's narrative, as well as the mastery of her aesthetics (The Hour, 1986).

In April of the same year, in the exact month when A-Hora's translation into English had been launched, Bricklebank (1986) unknowingly echoed Medeiros (1977) and Junqueira (1977), and contradicted Habib (1977)

by acknowledging Lispector's power for introspection. Without paying much attention to linguistic and social aspects, per se, Bricklebank frames the novel as philosophical fiction, commending it to those who are interested in novels of that nature.

In the following year, it was the moment for The New York Times and the Los Angeles Times to approach both Lispector's work and its homonymous movie adaptation by Suzana Amaral. Writing in the latter newspaper, Wilmington (1987) emphasized on the brutality, rawness and ugliness of the protagonist. He seemed impressed by the way in which Lispector so harshly revealed human crudeness, away from forced petrification and mitigation. Besides, Wilmington (1987) lauded Lispector's aesthetic ability to imprint on her novel so much irony and mockery, especially in a narrative that is expected to be warm-hearted and forthright.

Just like the commentator from the Los Angeles Times, the columnist from The New York Times (Maslin, 1987) paid greater attention to Amaral's homonymous movie than to Lispector's work. Even so, the same critic agreed with her colleague Wilmington (1987) with regard to the nature of the protagonist and Lispector's way of 
The Hour of the Star Through Media Lenses: A Tribute to Clarice Lispector (1920-2020)

constructing the latter. Then, Maslin (1987) added that Macabéa is a heroine like no other, completely the opposite of what one might expect. Nevertheless, unlike Wilmington, who explores the work of creation and interaction between narrator and heroine, the pundit focused on the novel's philosophical dimension as a consequence of Lispector's aesthetics.

In the 1990s, Barbara Mujica (1992) stressed on the aesthetic nature of A-Hora in her text to Americas. She described the novel as Lispector's inquiry into the nature of genres and fiction, as well as into literary art itself. At the end of the same decade, and exploring almost exclusively the movie and not the novel, Rich (1998) from The New York Times presented A-Hora as a part of the Brazilian sociocultural contexts, in which aesthetics both feed from the contexts and refracts them. For her, many tensions in the narrative, some of which were mentioned by Rawet (1979), signal conflicts of different orders, mostly connected to a clash of primitive vs. modern.

\section{Critical Reception in Foreign Media (2000 -2020)}

The beginning of the 2000s did not bring significant or numerous reflections on A-Hora. However, the end of this first decade was marked by the first step towards a great awakening of the general public and foreign critics with regard to Clarice Lispector, particularly concerning A-Hora and her famous short stories. It is likely that this movement has started in 2009 with the publication of Why This World: A Biography of Clarice Lispector, by Benjamin Moser (2009).

Still in 2009, possibly inspired by that biography, the prestigious New York Review of Books published a concise reflection not only on A-Hora, but also on Lispector's life and work (Moore, 2009). Columnist and novelist Lorrie Moore began her review by contrasting different attitudes and sentiments of Brazilian and U.S. ${ }^{12}$ readers towards A-Hora, considering their comments on the Amazon platform. She explains that, whereas lusophone readers tend to praise Lispector's unusual and inventive style, English-speaking readers appear tepid, often confused, and averse to Lispector's eccentric language. At this point, it has to be added that the English translation of $A$-Hora which Moore (2009) referred to is the one produced by Giovanni Pontiero, who seems to significantly reduce the complexity of Lispector's morphosyntax, as suggested by Moser (2011).

In this sense, Moser himself announced later in 2011, in the magazine Publishing Perspectives, a new translation of A-Hora into English, carried out by himself in an attempt to avoid Pontiero's mistakes. Paying greater attention to linguistic aspects, evidently, in this announcement Moser reflected on how the «strange» and «unexpected» language of Lispector functions as a temptation to translators who might end up «correcting» her intrepid writing (2011, § 10-11). For him, this impulse towards regulating her language is understandable; nonetheless, it does a disservice to the Brazilian novelist, since by removing part of her linguistic eccentricity, translators also suppress the element which is perhaps most peculiar to her. Without this singularity, therefore, the Brazilian author's style would cease to exist in its plenitude (Moser, 2011). Accordingly, he believed that his 2011 translation is a second

12. The demonym American is not used in this paper, because America is not actually a country, but a continent. Accordingly, it should not be used to call only U.S. citizens, but also people who live in the Americas (Martinez, E. 2003). https://shorturl.at/hiwDT 
The Hour of the Star Through Media Lenses: A Tribute to Clarice Lispector (1920-2020)

chance for anglophone readers to fully appreciate $A$-Hora's «weirdness» and «novelty», showing greater potential to overcome the possible resistance mentioned by Moore (2009), when readers approach Pontiero's translation.

Still regarding translation, Magdalena Edwards (2012) agreed with Moser (2011), whereas Moore (2009) argued the exact opposite, by acclaiming Pontiero's translation of A-Hora. When comparing Moser's with Pontiero's version, Edwards noted that the former is more accurate and effective in communicating Lispector's style. As an expert in comparative literature, Edwards (2012) briefly contrasted samples from both translations, and although for her Pontiero stands out in some instances, Moser becomes more convincing, urban, and urgent; stranger and idiomatic, and therefore, closer to the sensation one might have when reading the original (Edwards, 2012).

From her experience as a translator, Edwards $(2012, \S 1)$ considered that the aesthetic quality of Lispector's language is the element that makes the narrative shine through. According to her, this is a «mind-blowing» novel, yet more accessible and more geographically located than Lispector's other works. At this point, it seems that Edwards refracted, on the one hand, the fact that Lispector might have conceded under the pressure of her time to create a more explicit and space-time situated narrative; and on the other hand, the columnist's view corresponded with Rawet's (1979), which indicates that Lispector would use the discourse of surrounding traditions —including more evident anchoring in social spaces - in order to transmute them into her own language.

Back to Moore's critique (2009); she argued that Lispector comes from a privileged family and that her many designed dresses, her socioeconomic position and her texts for a newspaper beauty section would turn her into a less valuable feminist, which could be refracted in her work: «She was a kind of feminist, but as someone who [...] had a closet full of designer dresses, she was not a feminist's feminist» (Moore, 2009, § 4). Others disagree with that position. Kehoe (2014), for example, suggests that Lispector had never felt comfortable in those prestigious social circles, a sense of social inadequacy that would to some extent emerge in A-Hora.

As Moore introduced Lispector and her work, the commentator seemed increasingly willing to side with those readers who are unable to understand A-Hora, among other works. For the U.S. columnist, Lispector had a slight and merely aesthetic interest in poverty and the poor, transforming them into philosophy or existential symbols, in the manner of a ventriloquist who apathetically manipulates her working tools (Moore, 2009, § 6). Dialoguing with poet Ivo Lêdo's appraisal, Moore (2009) also suggested that Lispector's eccentric language would be much more of an effect of her daily unconventional Portuguese than due to an aesthetic laboriousness (Walsh, 2020). Hence, Moore $(2009, \S 6)$ believed that A-Hora and many other works by Lispector are a «shipwreck of introspection». She also maintained that the psychologism emerging from that language and introspection is intense, diffuse and hysterical.

On the other hand, and contrary to Elizabeth Bishop's understanding — which indicated Lispector not only as a primitive and brilliant short-story teller, but also as a «bad» novelist who «read nothing» (Bishop, cited in Moore, 2009, § 4) - Moore recognized that A-Hora is a result of a lively intelligence. She also admitted, as few critics previously, that the novel is ingeniously tragicomic. Hence, humor and tragedy are essential to the vitality 
of $A$-Hora's prose (Moore, 2009).

In the years following, other than Moser's biography of Lispector and his A-Hora translation into English, published in the first half of 2020, there has been a profusion of articles in foreign publications about the novel, especially due to its relaunching by Penguin Classics (Kehoe, 2014; Shakespeare, 2014; Evans, 2014; Tóibín, 2014; Gildea, 2014; Kofman, 2015; Cronin, 2015; Ha, 2015a; Vidal, 2015; Esposito, 2017). Furthermore, 2018 and 2019 might be considered another period of foreign revival for A-Hora and its author, as implied by Shook (2018) and Morgan (2019), among others (Kakitani, 2018; Dennis, 2018; Broida, 2019, Stobbs, 2019; Galchen, 2020; Walsh, 2020). From media publications in North America to the ones in Western Europe, from Ireland to Australia, from young observers to senior scholars, a significant number of critics have continued to introduce new viewpoints and perceptions about the density that Lispector shows in her novel. They all appear eager to preserve alive the exceptionality of a creation that keeps on attracting readers from several nations and linguistic backgrounds, even 40 years after its first publication and 100 years after its author's birth.

In the multitude of these latter media texts, there are some themes, however, that are more frequently explored with regard to Lispector and A-Hora, namely: i) the nature of Lispector's aesthetic, ii) A-Hora and Lispector's place in the literary pantheon, iii) A-Hora's aesthetic effects on readers, iv) Lispector's ability to incorporate void in her aesthetics, v) connections between the author's life and her work, vi) the emerging philosophy in $A$-Hora, vii) interactions between humor and tragedy, viii) feminism in her writing, and ix) exploration of the social dimension.

With respect to the first element, some critics understand that Lispector's frustration with a pressure that required her to tell a story inside a certain «square» might have prompted her to keep on transgressing standards from literature, both in terms of narrative structure and in the use of language itself, as well as in the creation of characters and their internal worlds (Kehoe, 2014; Evans, 2014; Gildea, 2014), so much so that some pundits indicate a transgressive non-literariness as a quality of her work (Shakespeare, 2014; Kofman, 2015). In fact, this anomalous nature of $A$-Hora used to make editors avoid Lispector as a «plague» (Shakespeare, 2014, § 2).

Even so, Lispector's ingenuity and linguistic refinement are so pervasive and distinctive that Kofman (2015) and Walsh (2020) imply that in A-Hora there is not only a philosophical language, but also a philosophy of language; «bizarre», «challenging» and «dazzling» (Ha 2015a, § 2). In this sense, Walsh echoed Moser's critique when she argued, citing a passage from A-Hora, that in Lispector's philosophy the language does not represent anything at all, but only itself (Lispector, cited in Walsh, 2020, § 9). Due to this positioning, Walsh (2020) ended up dialoguing with Moser (2009) and - unknowingly - Portella (1977), who required from A-Hora a more representational language; and also, with Rawet (1979), whose understanding sublimates Lispector's aesthetics, opposing, therefore, that pressure for the representational.

From another perspective on aesthetics, Dennis $(2018, \S 7)$ explained that Lispector's language and style both demonstrate the lexical-semantic immensity of Portuguese ——which «far expands [beyond] that of English»— and make A-Hora's text very unstable. Hence, for her, only the interaction between the narrator and the public 
The Hour of the Star Through Media Lenses: A Tribute to Clarice Lispector (1920-2020)

would remain constant, concealing and revealing, however, things the common reader expects to find out easily or laboriously.

In the same vein, the renowned Irish writer Tóibín (2014), in his text for The Guardian, expanded the abovementioned perception of uncertainty by maintaining that nothing is stable in Lispector's texts, which coincides with a «Brazilian lassitude» and «unreliability» pointed out by poet Elizabeth Bishop as features of Lispector's works (Bishop, cited in Moore, 2009, § 4). In this sense, Tóibín (2014) added that no one handles the following types of powerlessness better than Lispector in A-Hora: the narrator and the protagonist's ones. For him, most of an author's last works possess a spectral beauty in which form and content dance a slow and resourceful waltz; nevertheless, he believes that Lispector wrote $A$-Hora «as though her life was beginning, with a sense of a need to stir and shake narrative itself to see where it might take her» (Tóibín, 2014, § 14).

As for the second them, regarding to A-Hora and Lispector's place in the pantheon of literature, the novel is constantly compared to or contrasted with creations by other notable writers, such as Laurence Sterne, Flann O’Brien, Jorge Luis Borges (Kehoe, 2014), James Joyce, Virginia Woolf and Vladimir Nabokov (Shakespeare, 2014; Cronin, 2015; Stobbs, 2019; Broida, 2019; Rabassa, 2005, cited in Ha, 2015b). Broida (2019), for example, noticed that the use of «yes» as the opening and closing of $A$-Hora is evidence of the contact between Lispector and James Joyce, considering that the latter also built a philosophical atmosphere around the term «yes». Some columnists, on the other hand, echo opinions by literary scholars such as Sérgio Milliet — for whom Lispector «succumbs beneath the weight of her own richness» (Milliet, cited in Broida, 2019, § 3) — and Hélène Cixous, whose appraisal maintains Lispector as a female version of Franz Kafka, a Brazilian apparition of Rainer Rilke, an Arthur Rimbaud had he been a mother, and a Latin reincarnation of Martin Heidegger (Cixous, cited in Kofman, $2015, \S 23)$. Other critics avoid comparing her, by stating that Lispector is unique and absolutely economic in language as perhaps no other writer has been (Walsh, 2020; Tóibin, 2014; Stobbs, 2019).

Concerning the third theme, the effects of Lispector's aesthetics on A-Hora readers, Kehoe (2014) and Walsh (2020) believed that the author clearly distinguished who is part of her audience: an experienced and extremely sensitive reader (Vasquez, cited in Maciel, 2017). Walsh (2020, § 1) explains that by reading A-Hora, inexperienced readers will feel the ground «sliding from under their feet» and they will be terrified and powerless in the face of Lispector's aesthetics (Walsh, 2020). Similarly, Kehoe (2014) highlighted the several pauses and reflections he had to make throughout the reading and how A-Hora is composed like poetry verses, given its potency and charm. Vidal $(2015, \S 8)$ agreed and explained that reading Lispector is like handling «blazing worlds» about to explode at any moment, but which the reader wishes to keep because of their melancholy and profoundness of meaning. Such a singularity makes translation a painful process, says El Gebaly, responsible for the first version of $A$-Hora in Arabic (Brazil-Arab, 2018).

For Galchen (2020), nonetheless, A-Hora is legible, charming and even easier than other works by Lispector, such as Água viva (1973). Stobbs (2019) noticed that for some, however, Lispector's language might become inaccessible or appear pretentious, since her style is sharp and relentless to less skilled readers. Notwithstanding, 
The Hour of the Star Through Media Lenses: A Tribute to Clarice Lispector (1920-2020)

Stobbs also believed that $A$-Hora is a rare, instigating and memorable novel.

By contrast, among those who express reservations about A-Hora and Lispector's style, there is a columnist for the British newspaper The Telegraph (Shakespeare, 2014). Following Alfred Knopf Jr.'s opinion —Knopf was a renowned publisher who has reportedly boasted not to have understood a word of $A$ maçã no escuro (1961) $)^{13}$ [translated as Apple in the Dark (1967)] $]^{14}$ — Shakespeare noted that A-Hora's acclamation cannot be confirmed in his reading. Explaining the reasons behind his disappointment with Lispector's work, the novelist stated that A-Hora makes no sense to him, since it lacks «plot, character development, lucidity, precision, irony, excitement and humor» (Shakespeare, 2014, § 13). Dissatisfied with this reading experience, Shakespeare (2014, § 13) argued that, by placing Lispector side by side with Franz Kafka, Virginia Woolf and James Joyce, her «strident champions» remind him of what those writers are not.

On another note, when reporting about the fourth aspect, Lispector's ability to incorporate void in her aesthetics, among other elements, Shakespeare (2014, § 13) also emphasized that A-Hora's author became «insensitive» and «morbid». In the opposing sense, Gildea (2014, § 11; Stobbs, 2019) demonstrated that A-Hora is strangely «humanistic» and «heartfelt». For him, A-Hora «suffers none of the sterile academic tone often associated with post-modern works.»

On this dispute about what the void means not only in A-Hora, but also in most of Lispector's works, The Nation Kofman $(2015, \S 9)$ suggested that Lispector continued «wrestling with the void where language is not. » With that remark, Kofman unknowingly reproduced part of José Castello's critique, one of the first scholars to defend this idea, which is later quoted by Moser (2011). In the same vein, Kofman $(2015, \S 6)$ pointed out that Lispector's favorite words were «mute» and «silence», because it is this void, embodied in words such as these, that prompted her to create worlds. Walsh $(2020, \S 15)$ took this assumption even further and considered that «the "empty", encircled by a form, outlined and given shape by the form that isn't really there» is the essence that Lispector was searching for through her writing.

Another aspect in A-Hora that appears quite explored is the fifth theme: the connection between the author's life and work. A significant number of newspapers and magazines referenced in this paper reinforced or replicated myths formed around Lispector, her life and creation (Shakespeare, 2014; Kofman, 2015; Ha, 2015; Esposito, 2017; Edwards, cited in Shook, 2018; Walsh, 2020; Galchen, 2020). Whether for their unusual nature, or for the constant pressure journalists come under to attract more readers, legends about Lispector are described in those periodicals with a wealth of details, in a style that is comparable to the way some tabloids report on celebrities.

Beautiful, weird, elusive, unreliable, introspective, nebulous, inexplicable, mysterious, «witch», «communist», «lesbian», a «man» or a «diplomat» are some of the keywords used to characterize her or introduce myths around her (Tóibín, 2014; Shakespeare, 2014; Kofman, 2015; Esposito, 2017; Galchen, 2020; Walsh, 2020). Columnists seek, therefore, to operate an implicit dialogue between this mythology and the constitution of Lispector's writing

\footnotetext{
13. Lispector, C. (1961). A maçã no escuro. Rio de Janeiro: Livraria Francisco Alves Editora.

14. Lispector, C. (1967). The Apple in the Dark. New York: Knopf.
} 
The Hour of the Star Through Media Lenses: A Tribute to Clarice Lispector (1920-2020)

itself, especially through comparisons, suggesting that A-Hora's eccentricity bears some relation to her persona. Two of those commentators seemed to synthetize this celebrity perspective that is constructed in many media texts. One states that publishers such as Penguin Classics «have caught the Lispector bug», so «obsessed» are they with A-Hora and other of Lispector's works (Shakespeare, 2014, § 3). The other, during an interview with the prestigious magazine Los Angeles Review of Books (Edwards, cited in Shook, 2018, § 20) understood that A-Hora, given its «easier» access in relation to other novels of Lispector, «is an essential text that offers a recipe for what to do if Clarice herself becomes an international export commodity like Coca-Cola or Marilyn Monroe.»

Notwithstanding this pervasive tendency towards celebrity culture and the «superfluous», the profound or the philosophical dimension of $A$-Hora is also a frequent topic in review texts on the novel. For some, existentialism seems to be the most evident element throughout $A$-Hora's elucubrations (Gildea, 2014). Not fortuitously, many have compared it to works by Franz Kafka, a renowned existentialist novelist. Others point out $A$-Hora's ability to «dig deeply into the dark abyss of the human condition» (Dennis, 2018, § 8). Stobbs (2019) highlighted, however, that more than a contemplation on human life, A-Hora carries out an intricate philosophical reflection about the writing process. Whereas James Joyce required hundreds of pages to do something similar, Stobbs believed that Lispector manages to be philosophically dense and powerful using much fewer pages. Dennis (2018), in her turn, after reproducing Hélène Cixous, summarized the relevance of the philosophy in Lispector: «there, further ahead, where the philosopher loses his breath, she continues, still further, beyond all knowledge» (Cixous, cited in Dennis, 2018, § 8).

Regarding the seventh the theme, the interaction between humor and tragedy, an aspect few commentators discuss (Moore, 2009), Dennis is also impressed by the ways through which crude irony, sarcasm and satire enable A-Hora to become a beautifully tragic novel, filled with multiple layers of meaning, which are distinctly explored every time readers return to the text (Dennis, 2018). Even so, the Australian columnist believed that she lost some of those levels of meaning by reading A-Hora in English, because she also thought that this language does not admit the same semantic density concerning the relations between humor and tragedy as the original in Portuguese does.

Likewise, Tóibín (2014) emphasized on Lispector's mastery for combining humor and tragedy in A-Hora. The commentator explained that the extreme care and delicacy in Lispector's writing create an occasion for fine conjunctions between irony, mockery and pain, whether they occur on the stage — where Macabéa is - or in the backstage — where Rodrigo S. M. is — . Tóibín $(2014, \S 11)$ concluded that only Lispector's style is able to exercise, at the same time, «a deep awareness about the tragedy of being alive [and] a sly allowance for the fact that existence is a comedy.»

Another less explored element in A-Hora is the feminist theme. Actually, some critics only mention aspects of feminism when presenting the author's personal life, as for instance the contrast between her image as a «sphinx» and a «housewife» (Ha, 2015b, $\S 7)$, or between her representation as a volitional, free person and a diplomat's spouse (Esposito, 2017; La Cava, 2015), or yet the exploration of the idea that Lispector would be a lower-value 
The Hour of the Star Through Media Lenses: A Tribute to Clarice Lispector (1920-2020)

feminist (Moore, 2009). Stobbs (2019) is one of the few columnists who overcame subjects such as fashion and the Lispector's domestic and public life in order to approach feminism in the novel itself, although she did it for a very brief moment. For the British commentator, gender politics is one of the crucial themes in $A$-Hora, as Lispector both satirized patriarchy and pointed out the exploitation of women through a very peculiar «magical realism» (Stobbs, 2019, § 10).

In that sense, Stobbs (2019) is also one of the few critics who approachd A-Hora's social dimension, which draws even less attention than the previous aspect. Unlike the social debate carried out by Arêas (1977) and Ribeiro (1977), or the notion that Lispector would «aestheticize» poverty (Moore, 2009), Stobbs (2019) argued that the same «magical realism» that works as lens through which the condition of women is analyzed also helps to shine some light on socioeconomic issues, such as impoverishment, the destructive power of consumerist capitalism, or inequality between classes, as suggested by Gildea (2014). Therefore, without appearing enigmatic and focusing on aesthetics, Tóibín quoted Hélène Cixous to synthetize his view on the social dimension of $A$-Hora: «it is a text about poverty that is not poor» (Cixous, cited in Tóibín, 2014, § 12).

\section{Conclusion}

As implied in the previous sections, media reception of $A$-Hora often refracts or partially reproduces critical positions taken by professionals who usually work outside magazines and newspapers, and inside academia (Ha, 2015b). In some instances, journalists and other lay individuals, who have no prior education in literary theory and analysis, are the ones providing their own evaluation of a novel that seems quite complex; in this sense, it is perhaps necessary not to take their words at face value, avoiding their immediate legitimation as statements of a sage, a periodicalist or a man of letters of current times. On other occasions, literary writers work as columnists for periodicals, expressing, therefore, their opinions as both critics and artists, for example, Tóibín (2014). Hence, as is to be expected, media discourse on literature also tends to be «parasitic», that is, it depends on other discourses outside its scope in order to function effectively, validating itself, obtaining more consistency and reaching diverse audiences.

In the case of Brazilian magazines and newspapers, the assessment of A-Hora also takes place through a dialogue between columnists themselves, especially when disagreeing with each other, as happened to Rawet (1979) and Portella (1977), among others. When exploring the nature and quality of A-Hora, these first Brazilian media texts seem to concentrate on two axes of discussion: one related to the contrast between Lispector's introspection (Medeiros, 1977; Junqueira, 1977) and explicitness (Habib, 1977), or between an intimate style and social engagement (Arêas, 1977; Ribeiro, 1977); and another one regarding a transgressive freedom to create (Rawet, 1979) and a demand for representational commitment in the construction of Brazilian identities through fiction (Portella, 1977). The foci of these debates were later echoed in different degrees and forms across media texts, not just in Brazil but also abroad. However, some components of these axes, such as the author's 
The Hour of the Star Through Media Lenses: A Tribute to Clarice Lispector (1920-2020)

explicitness and social engagement in A-Hora, tend to be pushed to the background or disappear, especially in debates presented in foreign media.

Be that as it may, some recent texts in Brazilian media still reinforce Lispector's intimism and aesthetic innovation in A-Hora (Moscovich, 2017; Maciel, 2017) as they point out the versatility of this narrative in adaptations for other multimodal genres, such as plays, musicals and movies (A Hora, 2017). Accordingly, from a more pedagogical perspective, they try to connect the themes of the novel with everyday life as well as feminist issues, also deepening discussions about the philosophical nature of Lispector's narrative (Ianelli, 2019; Guedes, 2015; Alves, 2008).

In media texts that evaluate $A$-Hora in foreign publications, however, due to their slightly higher number and more directed emphasis, at least nine themes through which $A$-Hora has been discussed were identified (see Section 4). The first one suggests that commentators' feelings ranged from uncomfortable to amazed in the face of the aesthetic eccentricity and depth of A-Hora. The second one points out that most critics believe that Lispector and all her works certainly have a place among the great authors of both Latin American and world literature, although a few might differ. The third one demonstrates that Lispector's style divides readers, often displeasing or unsettling the anglophone ones; in this sense, it is still a matter of debate whether translation significantly hinders comprehension of the novel. The fourth one might refer to a controversy: whereas for some critics Lispector's work with the void makes the novel morbid and insensitive, most of them believe it makes the narrative powerful, universal and heartfelt.

Debates under the fifth theme, on the other hand, indicate that media texts created a significant space for the exploration of perspectives that seem more superfluous, such as a celebrity culture regarding relations between Lispector's life and work. For some, approaching interactions between the concrete person and the author might create problems of interpretation, but most of those who apply to that endeavor seem to do it more for the sake of enticing readers and perhaps satisfying their own curiosity than for the sake of a fuller understanding of the novel.

The sixth theme suggests that Lispector engages in some form of dialogue with existentialism, as others did before her, but some columnists take this perception further by arguing that A-Hora is not just about the use of language with a philosophical nature, but is also a philosophy of language. The seventh theme reveals that A-Hora's ingenious combination of humor and tragedy is largely intensified by the coexistence of a backstage narrator and a stage protagonist, not to mention all the many layers of subtle meaning through which Lispector created mockery and pain, despite the translations were not able to fully convey them as the original does.

The eighth theme does not draw much attention from critics, unless it is somehow related to curiosities of Lispector's private or public life. When some critics do discuss it more seriously, they emphasize that gender politics and satire on patriarchy are very much alive throughout Lispector's novel. The last aspect, although not such a popular viewpoint either, has been part of debates on A-Hora since the 1970s, as mentioned before. This might also be considered as another point of contention between critics: whereas some recognize that $A$-Hora exposes socioeconomic inequality, impoverishment and consumerism, others continue to focus on the aesthetics 
and argue that such issues are transformed into mere aesthetic objects.

All in all, the aesthetic dimension of A-Hora - language included — seem to come first in media texts, followed by debates on its philosophical values and implications. Furthermore, connecting Lispector's private and public life with the quality of her novel also settles a trend in a significant number of media texts, which could possibly make publications more attractive to those who have never heard of the Brazilian author, increasing, perhaps, the levels of readership in the same manner tabloids entice their interlocutors. Under these circumstances, Lispector's charisma, like her art, still proves to be worthy of attention after so many decades, despite the unusual, defying, intrinsic or even «inaccessible» nature of her writing. In this sense, her novels might not be as inviting as some «easier» narratives readers are accustomed to, but her persona is certainly able to intrigue even the most skeptical interlocutors, starting with the columnists who dedicate a reasonable amount of time to try to find out who she is and how they should be able to introduce her to diverse audiences without diminishing or restraining the full potential of her uniqueness.

Therefore, acknowledging Lispector's contributions to literature in Brazil and elsewhere requires an effort to overcome the categories that many readers attempt to impose on her. Although A-Hora has been compared many times, Lispector's novels are not the same as James Joyce's, Virginia Woolf's, Franz Kafka's or even less Jorge Luís Borges' works. She seems to really challenge orthodox classifications, although still being part of the Latin American literary boom of the 20th century, alongside an all-male list of Latin colleagues, such as Mario Vargas Llosa, Jorge Luis Borges, Gabriel García Márquez and Julio Cortázar (Fernández-Lamarque, 2016). In such a way, any attempt to label her transgressive works might end up turning her into someone she is not or neglecting the new perspectives she is truly bringing into literature. On the other hand, equating Lispector's narrative to those of European authors can only remind us that the Latina artist is neither inferior nor superior to any other writer, she is simply divergent and should primarily be understood through her own alterity. Thus, despite not being unanimously acclaimed in media everywhere or by every scholar, Lispector's and A-Hora's place among the great authors and works of the world is unquestionably more than deserved. 


\section{Bibliographical References}

1. Alves, B. R. (June 21, 2008). Clarice Lispector: A hora da estrela. Diário do Nordeste.

2. Arêas, V. (November 29, 1977). Que mistérios tem Clarice. Folha de São Paulo.

3. Becherucci, B. (July 31, 1974). Lixo, sim: lançamento inútil. Veja.

4. Béra, M. (2003). Critique d'art et/ou promotion culturelle. Réseaux, 117(1), 155-187.

5. Brazil-Arab News (August 6, 2018). Lispector Novel Published in Egypt. Brazil-Arab News.

6. Bricklebank, P. (April 15, 1986). The Hour of the Star. Library Journal, 111(7), 96.

7. Broida, M. (April 30, 2019). The Siege of Clarice Lispector. The Paris Review.

8. Cancino, C. A. (October 8, 1999). A Hora da Estrela volta à cidade grande. Folha de São Paulo.

9. Costa, I. (August 9, 2017). A HORA da estrela, de Clarice Lispector, será adaptada para musical. O Povo.

10. Cronin, B. (August 10, 2015). Lispector: Brazil's Virginia Woolf. The Wal Street Journal.

11. Day, G. (2008). Literary Criticism: A New History. Edinburgh: Edinburgh University Press.

12. Dennis, O. (July 2, 2018). The Hour of the Star: A Philosophical and Piercing Introduction to Brazilian Literature. Lindsay Magazine.

13. Dodson, K. (2017). Literature: Rediscovering Clarice Through Translation. Berkeley Review of Latin American Studies (Spring 2017).

14. Eagleton, T. (2005). The Function of Criticism. London: Verso.

15. Edwards, M. (January 11, 2012). My Hour of the Star: On Clarice Lispector. The Millions.

16. Esposito, S. (July 25, 2017). How Witchcraft of Clarice Lispector Saved My Life. Literary Hub.

17. Evans, C. J. (April 24, 2014). The Genius of Clarice Lispector. Music \& Literature.

18. Fernández-Lamarque, M. (2016). Espacios posmodernos en la literatura latinoamericana contemporánea: distopías y heterotopías. Buenos Aires: Argus-A.

19. Galchen, R. (2020). Her Big Horse Face. London Review of Books, 42(7), April 2020.

20. Gildea, K. (July 12, 2014). If You Were to Read a Lispector's Book, Which Should It Be? Irish Times.

21. Goldman, N. (March 30, 2018). Clarice Lispector's Lifelong Project. The Nation.

22. Guedes, D. (August 2, 2015). A crítica americana se rende a Lispector. Jornal do Commercio.

23. Ha, T.-H. (August 21, 2015a). Clarice Lispector's Magical Prose. The Atlantic.

24. Ha, T.-H. (August 21, 2015b). The Literary World's New Breakout Cult Writer Has Been Dead for Almost 40 Years. Quartz.

25. Habermas, J. (1991). The Structural Transformation of the Public Sphere: An Inquiry Into a Category of Bourgeois Society. Boston: MIT Press.

26. Habib, M. A. R. (2005). A History of Literary Criticism: From Plato to the Present. Carlton: Blackwell. 27. Habib, S. (October 29, 1977). Clarice Lispector: outro mergulho mágico. Jornal de Brasília.

28. Ianelli, M. (December 10, 2019). Clarice Lispector: uma sugestão de roteiro de leitura. O Estado de São Paulo. 
The Hour of the Star Through Media Lenses: A Tribute to Clarice Lispector (1920-2020)

29. Junqueira, I. (October 23, 1977). Lispector: insólita, solitária, romancista total. $O$ Globo.

30. Kehoe, P. (May 14, 2014). The Hour of the Star: Clarice Lispector. RTÉ-Ireland's National Television and Radio Broadcaster.

31. Kellogg, C. (June 13, 2019). Rediscovering Clarice Lispector, the Brazilian Author Who Blurs the Lines of Dreams. Los Angeles Times.

32. Jornal do Brasil (June 21, 1986). A HORA da estrela de Suzana Amaral. Jornal do Brasil.

33. Kirkus Review Magazine (March 15, 1986). The Hour of the Star. Kirkus Reviews Issue.

34. Kofman, A. (2015, November 5). Not the Word, but the Thing Itself. The Nation.

35. Lacava, S. (August 3, 2015). Found in Translation: The Complete Stories of Clarice Lispector. Los Angeles Review of Books.

36. Larceneux, E. (2001). Critical Opinion as a Tool in the Marketing of Cultural Products: The 37. Experiential Label. International Journal of Arts Management, 3(2), 60-71.

38. Lerner, J. (Director) (January 16, 1977). Trechos, o novo livro de Clarice Lispector. Panorama. TV2 Cultura.

39. Lispector, C. (November 8, 1976). Clarice Lispector x Editores. Folha de São Paulo.

40. Lispector, C. (August 25, 1977). Clarice Lispector. Mais um livro e a mesma solidão. O Globo.

41. Lispector, C. (1977). A hora da estrela. Rio de Janeiro: Livraria José Olympio Editora.

42. Lispector, C. (1986). The Hour of the Star. Pontiero, G. (trans.). Manchester: Carcanet Press.

43. Lispector, C. (2011). The Hour of the Star. Moser, B. (trans.). New York: New Directions.

44. Maciel, N. (May 29, 2017). A hora da estrela, de Lispector, com. 40 anos. Correio Braziliense.

45. Maslin, J. (January 21, 1987). Screen: Hour of the Star, Brazil. The New York Times.

46. Medeiros, B. (November 26, 1977). Solitária, solidária. Jornal do Brasil.

47. Moore, L. (September 24, 2009). The Brazilian Sphinx. The New York Review of Books.

48. Moraes, E. (August 17, 1974). A via-crucis de Clarice. Jornal do Brasil.

49. Morgan, A. (August 19, 2019). The Great Clarice Lispector Revival. Electric Literature.

50. Moscovich, C. (December 7, 2017). Saiba por que você precisa (re)ler A hora da estrela, de Clarice Lispector. Zero Hora.

51. Moser, B. (2009). Why This World: A Biography of Clarice Lispector. New York: OUP.

52. Moser, B. (December 2, 2011). Brazil's Clarice Lispector Gets a Second Chance in English. Publishing Perspective.

53. Moser, B. (July 10, 2015). The True Glamour of Clarice Lispector. The New Yorker.

54. Moser, B. (2020). The Hour of the Star: 100th Anniversary Edition. (2020). Amazon.

55. Mujica, B. (1992). The Hour of the Star. Americas, 44(1), 61.

56. Portella, E. (1977). O grito do silêncio. Tempo Brasileiro: Revista de Cultura, 51(1), 8-10.

57. Rawet, S. (2008 [1979]). A hora da estrela ou as frutas da frota, ou um ensaio de crítica literária policial. In Santos, F. V. D. (Ed.), Fortuna crítica em jornais e revistas. Rio de Janeiro: Caetés. 
The Hour of the Star Through Media Lenses: A Tribute to Clarice Lispector (1920-2020)

58. Rawet, S. (March 11, 1979). A hora da estrela ou as frutas da frota, ou um ensaio de crítica literária policial. Minas Gerais Suplemento Literário, 8-9.

59. Revista Museu (December 5, 2019). Obra completa de Clarice Lispector é reeditada em comemoração ao seu centenário. Jornal do Brasil.

60. Ribeiro, L. G. (November 19, 1977). A Hora das Estrelas. Jornal da Tarde.

61. Rich, B. R. (November 29, 1998). Cinema That Rolls with the Politics. The New York Times.

62. Sgard, J. (1994). La critique est aisée. In J. L. Roux (Ed.), Critiquer la critique İ Culture et médias, l'impossible mariage de raison (pp. 13-22). Grenoble: Ellug.

63. Shakespeare, N. (February 1, 2014). Clarice Lispector: Morbidly Insensitive. The Telegraph.

64. Shook, D. (November 23, 2018). The Real Clarice: A Conversation with Magdalena Edwards. Los Angeles Review of Books.

65. Stobbs, A. (January 31, 2019). The Hour of the Star, by Clarice Lispector. The Boar.

66. Tóibín, C. (January 18, 2014). Clarice Lispector's The Hour of the Star is as Bewildering as it is Brilliant. The Guardian.

67. Vidal, J. (August 15, 2015). The Blazing World of Clarice Lispector, in «Complete Stories». National Public Radio.

68. Walsh, M. (2020). Lispector: The Thereness of Language. Border Crossings, 153(1), March 2020. 69. Wilmington, M. (February 25, 1987). Star: A Ruthless Look at Ugly Duckling. Los Angeles Times. 70. Zero Hora (December 19, 2019). Ano do centenário de Clarice Lispector, 2020 terá série de lançamentos que lembrarão vida e obra da escritora. Zero Hora. 